УДК 373.3.016:37.091

DOI:

Геннадій Бондаренко, кандидат педагогічних наук, доцент, завідувач кафедри початкової освіти Педагогічного інституту Київського університету імені Бориса Грінченка

Олена Ващенко, кандидат педагогічних наук доцент, дочент кафедри початкової освіти Педагогічного інституту Київського університету імені Бориса Грінченка

\title{
МЕТОДИЧНІ ОСНОВИ ОРГАНІЗАЦІЇ ОЗДОРОВЧОЇ ДІЯЛЬНОСТІ МАЙБУТНЬОГО ВЧИТЕЛЯ ПОЧАТКОВОЇ ШКОЛИ В ГРУПІ ПОДОВЖЕНОГО ДНЯ
}

Стаття присвячена розгляду методичних аспектів оздоровчої діяльності вчителя початкових класів у групі подовженого дня. З'ясовано, изо проблемі організації оздоровчої діяльності майбутнього вчителя початкової школи в групі подовженого дня сучасні науковці та педагоги-практики надають важливого значення. Це пов 'язано з необхідністю виховання здорового покоління, яке свідомо ставиться як до свого так i здоров 'я навколишніх, формування у молодших школярів здоров 'язбережувальної компетентності і на уроках, і в позаурочний час, щуо є змістом найважливіших завдань в умовах Нової украӥнської школи.

Ключові слова: оздоровча діяльність; група подовженого дня; майбутній учитель початкових класів; молодиий школяр.

Jim. 11.

Hennadii Bondarenko, Ph.D.(Pedagogy), Associate Professor, Head of the Primary School Education Department, Pedagogical Institute,

Kyiv Borys Hrinchenko University

Olena Vashchenko, Ph.D.(Pedagogy), Associate Professor, Associate Professor of the Primary School Education Department, Pedagogical Institute, Kyiv Borys Hrinchenko University

\section{METHODICAL FUNDAMENTALS OF ORGANIZATION OF HEALTH ACTIVITIES OF THE FUTURE PRIMARY SCHOOL TEACHER IN THE EXTENDED DAY GROUP}

The article is devoted to the consideration of methodological aspects of the health preservation activity of a primary school teacher in an extended day group. It has been found that modern scientists and educators-practitioners attach great importance to the problem of organizing the health activities of the future primary school teacher in the extended day group.

This is directly related to the to the need to educate a healthy generation that is conscious of both of their own health and the health of others, the development of health-preserving skills in younger students both in class and in extracurricular activities, which is the basis of the most relevant tasks of the New Ukrainian school project. The modern educational process of primary school aims to create conditions for teachers who are able to practically apply health preserving techniques, focusing on the best achievements of national and world science. The formation of the education system in Ukraine requires a conceptual rethinking of the professional training of future teachers. This is why nowadays the higher school institution faces an important task of training a teacher who is able not only to teach and educate students, but also to shape their health preserving culture, as well as the understanding of the importance of both to personal health and the health of others.

Therefore while obtaining a degree at the Pedagogical University the future teacher must acquire certain knowledge, skills and abilities regarding the organization and implementation of recreational activities with primary school students and, most importantly, during the students stay in the group for an extended day. student.

Keywords: health preservation activities; extended day group; future primary school teacher; primary school

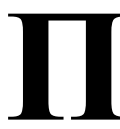

остановка проблеми. Утвердження загальнолюдських цінностей, збереження здоров'я громадян України $є$ винятково актуальною проблемою сьогодення. Інтерес до проблеми здоров'я викликаний насамперед соціальним замовленням суспільства на особистість, здатну до здорового способу життя та соціальної активності.

Формування здорового способу життя підростаючого покоління України належить до найактуальніших проблем, розв'язання яких визначає майбутнє держави та подальше існування здорової нації. Відповідно до концептуальних засад Концепції Нової української школи, стратегічним завданням сучасної освіти визначено виховання освіченої, творчої особистості, розвиток їі духовного, психічного та фізичного здоров'я. Саме тому, обов'язковим компонентом національної 


\section{МЕТОДИЧНІ ОСНОВИ ОРГАНІЗАЦІЇОЗДОРОВЧОЇ ДІЯЛЬНОСТІ МАЙБУТНЬОГО ВЧИТЕЛЯ ПОЧАТКОВОЇ ШКОЛИ В ГРУПІ ПОДОВЖЕНОГО ДНЯ}

системи освіти мають бути сформовані в учителя знання щодо збереження та зміцнення особистого здоров'я, а також професіоналізм як показник його конкурентоспроможності. Однією з обов'язкових компетентностей вчителя початкових класів закладу загальної середньої освіти є його знання, вміння та навички відновлювати, зберігати та зміцнювати здоров'я учнів, тобто рівень і якість оволодіння ним оздоровчою діяльністю.

У дослідженнях науковців зазначається, що більшість педагогів не виокремлюють здоров'я як пріоритетну особистісну цінність, не оцінюють роль власних зусиль у збереженні та розвитку здоров'я, недостатньо ознайомлені 3 методами самодіагностики і саморегуляції стану здоров'я учнів, не володіють системою знань про здоров'я, комплексом навичок застосування технологій збереження та зміцнення як власного здоров'я, так і здоров'я учнів молодшого шкільного віку [8; $10 ; 11]$.

На сучасному етапі розвитку освіти пріоритетним є підготовка педагогів-професіоналів, орієнтованих на збереження здоров'я здобувачів початкової освіти. Проблема оздоровчої функції освіти складна й багатогранна, а їі реалізація залежить не тільки від бажання вчителів, але і від їхньої професійної готовності.

Сучасний освітній процес початкової школи має на меті створення умов для вчителів, здатних практично застосовувати оздоровчі методики, орієнтуючись на кращі здобутки національних та європейських наукових досліджень. Реформування системи освіти в Україні вимагає концептуального переосмислення фахової підготовки майбутніх учителів. Перед закладами вищої педагогічної освіти постає важливе завдання щодо підготовки вчителя, здатного не лише навчати і виховувати учнів, а й формувати їхню культуру здоров'я, ціннісне ставлення як до особистого, так і до здоров'я навколишніх. Тобто вже за час навчання у закладі вищої педагогічної освіти майбутній учитель повинен має мати сформовану здоров'язбережувальну професійну компетентність, зокрема щодо організації та здійснення оздоровчої діяльності з молодшими школярами і, передовсім, під час перебування учнів в групі подовженого дня [5].

Аналіз останніх досліджень і публікацій. Проблемі оздоровчої діяльності вчителя присвячені дослідження сучасних як вітчизняних, так і зарубіжних науковців, які розглядають іiі в різних аспектах (В. Бобрицька, Г. Бондаренко, Т. Бойченко, Є. Булич, О. Ващенко, В. Горащук, Н. Денисенко, О. Дубогай, В. Зайцев, С. Кондратюк, С. Лапаєнко, О. Мельник, О. Савченко, С. Свириденко, Т. Шаповалова, В. Шахненко та ін.).
Дослідження означених науковців доводять, що на сучасну школу покладається завдання виховання компетентної особистості, яка не тільки володіє знаннями в галузі зміцнення та збереження здоров'я, а й уміє застосовувати їх у житті, діяти адекватно у різних ситуаціях, адаптуватися до складних соціальних умов, долати життєві труднощі, підтримувати своє здоров'я. У цьому контексті актуалізується готовність учителя до формування у дітей молодшого шкільного віку знань, умінь і навичок збереження і зміцнення особистого здоров'я [8].

Формування навичок здорового способу життя у вчителів початкових класів передбачає реалізацію кожним із них професійно мотивованої, усвідомленої, тривалої у часі діяльності, спрямованої на поліпшення успадкованих резервів здоров'я, коригування індивідуальних форм життєдіяльності та способу життя. Результатом і головною метою цього процесу визначено формування у педагогів ціннісно-орієнтованих настанов на здоров'я та здоровий спосіб життя, складовою яких $є$ готовність до оволодіння знаннями, вміннями та навичками організації здорової життєдіяльності учнів [2]

Так, С. Кондратюк стверджує, що ставлення дитини до самої себе, свого фізичного розвитку зумовлюється найближчим оточенням, тому особистість учителя $\epsilon$ визначальною у формуванні настанов на здоровий спосіб життя i розвиток мотиваційно-потребової сфери саме в молодшому шкільному віці. Переконаність учителя має набувати прояву у практичній діяльності, адже взяти активну участь у формуванні здорового способу життя своїх учнів можуть лише ті з них, які мають знання, хорошу фізичну підготовку, досвід організації оздоровчих заходів із молодшими школярами [7].

Особливого значення, на думку Б. Долинського, набуває діяльність вчителя, пов'язана 3 формуванням культури здоров'я в молодших школярів, адже саме початкова здоров'язбережувальна освіта закладає підгрунтя здоров'я у житті дитини. Реалізувати це завдання, вважає дослідник, можливо лише завдяки усвідомленню вчителями важливості його значення у своїй професійній діяльності. Він також звертає увагу на необхідність формування у вчителів відповідної готовності - полікомпонентного стану особистості, забезпечує самореалізацію розв'язання здоров'язбережувальних завдань початкової освіти з урахуванням конкретних умов та особистісного досвіду, й охоплює мотиваційний, особистісний, когнітивний, діяльнісний і рефлексивний компоненти. Звідси визначаються 


\section{МЕТОДИЧНІ ОСНОВИ ОРГАНІЗАЦІЇ ОЗДОРОВЧОЇ ДІЯЛЬНОСТІ МАЙБУТНЬОГО ВЧИТЕЛЯ ПОЧАТКОВОЇ ШКОЛИ В ГРУПІ ПОДОВЖЕНОГО ДНЯ}

основні функції такої готовності: спонукальностимулювальна, спрямована на формування усвідомленого інтересу майбутніх вчителів до здоров'язбережувального навчання дітей; гносеологічна, що має на меті пізнання здоров'язбережувального процесу як об'єкта проєктування; проєктувальна, що виявляється в операційному забезпеченні особистісноорієнтованого здоров'язбережувального освітнього процесу; адаптації, що передбачає створення умов успішної роботи 3 підготовки до здоров’язбережувальної діяльності в початковій школі [6].

Соціальна важливість та необхідність розв'язаня проблем зміцнення здоров'я учнів початкової школи випливає зі стратегії здоров'язбережувальної освіти. Розкриваючи іiі, необхідно розглянути сутність базового поняття “формування готовності вчителя до організації оздоровчої діяльності в групі подовженого дня”, під яким розуміємо спосіб організації освітнього процесу, що гарантує збереження та зміцнення здоров'я всіх його суб'єктів, сприяє створенню здоров'язбережувального середовища в групі подовженого дня, яке формується у єдності педагогічних, психологічних та гігієнічних вимог. Наступне поняття - “оздоровча педагогічна діяльність”. Вона буде здійснюватися вчителями початкових класів за умов сформованості в них відповідної професійно-педагогічної спрямованості, оволодіння сукупністю психолого-педагогічних та здоров'язбережувальних умінь і навичок, якість засвоєння та надбання яких є необхідною умовою для здійснення означеної діяльності. Ця діяльність також має на меті - оволодіння певними формами і методами, завдяки яким майбутні вчителі можуть розв'язувати проблеми збереження здоров'я учнів, використовуючи при цьому розмаїття можливостей їхньої професійної діяльності, навчальну, позакласну роботу, оздоровчу діяльність на ГПД, педагогічне партнерство 3 батьками тощо. Засобами розв'язання цих питань у професійно-педагогічній діяльності вчителів можуть бути: здійснення здоров'язбережувальних заходів під час викладання навчальних дисциплін у початковій школі, організація та проведення виховних заходів фізкульурно-оздоровчого спрямування, дотримання санітарно-гігієнічних норм, використання ароматерапії та музикотерапії тощо [3].

Таким чином, на сьогодні проблема здоров'я нації $є$ не тільки предметом багатьох наукових досліджень, а й першочерговим завдання кожного закладу загальної середньої освіти. Саме тому проблемі формування готовності вчителів до оздоровчої діяльності в групі подовженого дня сучасні науковці та педагоги-практики надають особливого значення. Це пов'язано з необхідністю виховання здорового покоління, що свідомо ставиться до свого здоров'я та здоров'я навколишніх, формування у молодших школярів здоров'язбережувальної компетентності як на уроках, так і в групі подовженого дня, що є змістом найважливіших завдань сучасної початкової освіти.

Мета статті- проаналізувати і схарактеризувати методичні основи організації оздоровчої діяльності майбутнього вчителя початкових класів у групі подовженого дня в умовах НУШ.

Виклад основного матеріалу. Сучасна педагогічна наука характеризується переосмисленням та зміною багатьох поглядів іпідходів, відмовою від деяких усталених традицій та стереотипів. Тому завданням сучасного педагога є: відчувати тенденції інноваційних змін у системі освіти; розуміти сутність й особливості оздоровчих освітніх технологій, адаптувати їх до можливостей й особливостей учнівського колективу; вміти аналізувати й оцінювати ефективність їхнього використання [2].

Особливо важлива роль в організації збереження й зміцнення здоров'я дітей належить вчителю початкової школи, що зумовлено віковими особливостями молодших школярів. Дитина цього віку інтенсивно розвивається, організм, який формується, $є$ занадто чутливим до будь-яких несприятливих зовнішніх факторів. Учитель початкових класів як основний організатор освітнього процесу може систематично і найбільш ефективно впливати на фізичний та морально-духовний розвиток учнів, сприяти формуванню і зміцненню їхнього здоров'я.

Певний час дитина проводить у школі. Саме тому основним завданням освітнього процесу $є$ не тільки навчити, сформувати певні вміння та навички, розвинути творчий потенціал, а й максимально зберегти здоров'я учнів завдяки формуванню в них здоров'язбережувальної компетентності. Цьому допомагає використання в освітньому процесі здоров'язбережувальних технологій, якими має оволодіти вчитель початкової школи [2]. I вибір залежить від особливостей діяльності початкової школи, пріоритетних освітніх завдань, стану здоров'я учнів, їхніх інтересів та уподобань, врахування спрямованості засобів оздоровлення на вдосконалення основних показників фізичного розвитку дітей, наявного кадрового потенціалу, матеріально-технічного забезпечення, екологічних 


\section{МЕТОДИЧНІ ОСНОВИ ОРГАНІЗАЦІЇОЗДОРОВЧОЇ ДІЯЛЬНОСТІ МАЙБУТНЬОГО ВЧИТЕЛЯ ПОЧАТКОВОЇ ШКОЛИ В ГРУПІПОДОВЖЕНОГО ДНЯ}

факторів, рівня педагогічного партнерства 3 батьками учнів, усвідомлення ними значущості цілеспрямованої роботи збереження та зміцнення здоров'я дітей, можливостей ефективно здійснювати моніторинг результативності запроваджуваних технологій [10].

У Національній доктрині розвитку освіти України у XXI ст. (розділ “Здоров’я нації через освіту”) зазначається, що “державна політика в галузі освіти спрямована на забезпечення здоров'я людини в усіх іiі складових: духовній, соціальній, психічній, фізичний. Це здійснюються через розвиток ефективної оздоровчої освіти, повноцінне медичне обслуговування, оптимізацію режиму освітнього процесу, створення екологічно сприятливого життєвого простору, залучення до фізичної культури і спорту всіх учасників освітнього процесу" [9, 10-11].

Реалізація фізичної складової під час перебування учнів початкової школи в групі подовженого дня здійснюється через: фізкультпаузи, “години здоров'я”, рухливі ігри; контроль та самоконтроль за правильною поставою під час письма, читання, руху; використання вправ щодо профілактики сколіозу, запобігання гіподинамії; виконання дихальних вправ, гімнастики для очей, точкового самомасажу біологічно-активних точок обличчя й голови (концентрація уваги, втоми); навчання використовувати народні засоби оздоровлення та профілактики захворювань; знання особистого рівня здоров'я, навчання правильно та регулярно чистити зуби, дотримуватися режиму дня, харчування, праці, відпочинку [3].

Реалізація соціальної складової здоров'я під час перебування учнів початкових класів у групі подовженого здійснюється через використання засобів, які сприяють інтересу до оздоровчої діяльності, спрямованої на поліпшення їхнього соціального здоров'я; створення умов для самовираження учнів; стимулювання аргументації відповідей; заохочування ініціативи учнів; розвиток інтуїції, творчої уяви; здійснення взаємоконтролю; навчання дотримуватися правил спілкування у класі, в громадських місцях; формування вміння уникати конфліктних ситуацій за алгоритмом “Стій! Подумай! Прийми рішення!”; навчання гуманного ставлення до людей з особливими освітніми потребами [3].

Реалізація психічної складової здоров'я під час перебування учнів початкової школи в групі подовженого дня здійснюється через: створення сприятливого психологічного клімату в класі; формування в учнів позитивного мислення; використання освітніх засобів, що позитивно впливають на їх психічне здоров'я. А окрім того через формування вміння: керувати своїми емоціями, почуттями; бути впевненим щодо своїх можливостей, задатків; здійснювати самооцінку, самоконтроль; аналізувати наслідки впливу шкідливих звичок на здоров'я; приймати самостійно рішення в різних життєвих ситуаціях, вміння підтримувати дружні стосунки як 3 однолітками, так і з дорослими людьми [3].

Реалізація духовної складової здоров'я під час перебування учнів початкової школи в групі подовженого дня здійснюється через формування навичок: бачити й сприймати прекрасне в житті, природі, мистецтві, літературі; розрізняти зло і добро, духовне і бездуховне, долати прояви негативної поведінки [3]. Ця діяльність спрямовується також на: розвиток особистісних якостей (відповідальності за доручену справу, витривалості, впевненості у своїх силах, доброзичливості, самоповаги, цілеспрямованості, ціннісного ставлення до життя, здоров'я, природи, людей, навколишнього світу); подолання негативного ставлення до особистого здоров'я, життя, самого себе, до людей.

3 метою здійснення оздоровчої діяльності, спрямованої на збереження і зміцнення здоров'я дітей, які перебувають у групі подовженого дня, учитель початкової школи насамперед сам повинен усвідомлювати цінність здоров'я, відчувати себе суб'єктом оздоровчої діяльності. У дослідженнях сучасних науковців формування готовності вчителя до оздоровчої діяльності в групі подовженого дня розглядається як цілеспрямований процес його поетапного включення у здоров'язбережувальну діяльність на основі комплексу принципів, що забезпечують створення мотивації до прийняття концепції здорового способу життя, інтеграції інтелектуальної, фізичної і духовно-моральної діяльності вчителя, розвитку його загальної культури, формування готовності до ведення здорового способу життя [4].

Науковці доводять, що змістовим наповненням означеної діяльності $\epsilon$ формування уявлень майбутніх вчителів про здоров'язбережувальні технології та засоби зміцнення особистого здоров'я; а також потреби у психофізичному вдосконаленні, позитивному ставленні до свого здоров'я; практична діяльність вчителів щодо збереження та зміцнення здоров'я учнів [5; 6; 7].

Сучасному вчителеві початкової школи важливо правильно та раціонально використовувати методи та технології щодо здійснення оздоровчої діяльності в групі подовженого дня, оскільки дитина молодшого 


\section{МЕТОДИЧНІ ОСНОВИ ОРГАНІЗАЦІЇ ОЗДОРОВЧОЇ ДІЯЛЬНОСТІ МАЙБУТНЬОГО ВЧИТЕЛЯ ПОЧАТКОВОЇ ШКОЛИ В ГРУПІ ПОДОВЖЕНОГО ДНЯ}

шкільного віку повністю покладається на того, хто iii навчає та виховує. Майбутньому педагогу доцільно планувати свою діяльність з урахуванням ігрових технологій, що буде сприяти створенню атмосфери емоційного комфорту, зацікавленості та бажання дітей виконувати оздоровчі вправи.

Висновки. Таким чином, під час перебування молодших школярів у групі подовженого дня вчителеві необхідно здійснювати оздоровчу діяльність, спрямовану на формування у них основ свідомого ставлення до власного здоров'я, яка передбачає не лише надання знань про особисте здоров'я, а й має поєднуватися з формуванням в учнів умінь і навичок оздоровлення та зміцнення свого організму. Ми дійшли висновку, що оздоровча діяльність майбутнього учителя початкової школи в групі подовженого дня - це складний педагогічний процес, пов'язаний 3 організацією здоров'язбереження учнів, який передбачає впровадження фізкультурно-оздоровчих, екологічних, гігієнічних, психологічних, оздоровчих методик, що сприяють зміцненню, збереженню здоров'я молодших школярів та спрямовані на формування у групі подовженого дня здоров'язбережувального освітнього середовища.

Отже, формування готовності майбутнього вчителя початкових класів до організації оздоровчої діяльності в групі подовженого дня забезпечується завдяки сформованості певних мотивацій(усвідомленняважлиивостіздоров'язбережувальної діяльності,зацікавленості нею та бажанням досягти успіху); знаннями (особистіснозорієнтованих технологій правильного фізичного розвитку дитини та іiі здоров'язбереження; змісту форм, методів, технологій організації здоров'язбережувальної діяльності); уміннями розробляти сценарії оздоровчих заходів, організувати і проводити фізкультурно-оздоровчі та спортивно-масові заходи в групі подовженого дня; навичками систематично здійснювати самоаналіз професійної діяльності щодо узагальнення власного оздоровчого досвіду, спрямованого на формування здоров'язбережувальної компетентності молодших школярів.

Отже, основними методичними засадами організації оздоровчої діяльності майбутнього вчителя початкових класів у групі подовженого дня визначено такі: чітко визначена мета здоров'язбережувального виховання учнів; врахування останніх наукових досліджень, спрямованих на вивчення стану здоров'я учнів молодшого шкільного віку, що створюють підгрунтя для процесу формування їх здоров'язбережувальної компетентності; вимоги, відповідно до яких визначається ця компетентність; закономірності формування означеної компетентності в дітей; діагностика та оцінювання процесу оздоровчого виховання молодших школярів у групі подовженого дня; очікуваний результат.

\section{ЛIТЕРАТУРА}

1. Бобрицька В. І. Формування здорового способу життя у майбутніх учителів. Монографія. Полтава: Поліграф. центр “Скайтек”, 2006. 432 с.

2. Бондаренко Г.Л., Ващенко О.М. Аналіз результатів дослідження проблеми формування готовності майбутніх учителів до використання здоров'язбережувальних технологій у початковій школі. Міжнародний науковий журнал "Освіта і наука". 2019. 1 (26). С. 83-88.

3. Ващенко О. М., Свириденко С. О. Оздоровча робота на ГПД. Методичний порадник. Початкова освіта. 2008. C.3-11.

4. Ващенко О. М. Педагогічні умови організація здоров'язбережувального середовища початкової школи. Педагогіка здоров'я. Чернігів: Чернігівський нац. технол.ун-т, 2017. Т.1. С.119-125.

5. Ващенко О. М., Кікош О. В. Підготовка майбутнього вчителя до здоров'язбережувальної діяльності у початковій школі як наукова проблема. Перлини наукового пошуку: зб. наук. статей. Хмельницький: ХМЦНІ, 2014.Кн.2.С. 18-24.

6. Долинський Б.Т. Методологія здоров'язберігаючої діяльності майбутнього вчителя початкової школи. Монографія. Одеса: Видавець М. П. Черкасов, 2010.266 с.

7. Кондратюк С.М. Інтегративний підхід до виховання у молодших школярів здорового способу життя: автореф. дис. на здобуття ступеня канд. пед. наук: спеціальність 13.00.01. Київ, 2003. 20 с.

8. Науменко Ю.В. Здоров’язбережувальна діяльність школи. Педагогіка. 2005. С.37-44.

9. Національна доктрина розвитку освіти України у ХХІ столітті. Шкільний світ. Київ: 2001. 24 с.

10. Смирнов Н.К. Здоровьесберегающие образовательные технологии в современной школе. Москва: АПК и ПРО, 2002.121c.

11. Сократова Н.В. Современные технологии сохранения и укрепления здоровья детей: учебное пособие. Москва: Сфера, 2005. 224 с.

\section{REFERENCE}

1. Bobrytska, V. I. (2006). Formuvannia zdorovoho sposobu zhyttia u maibutnikh uchyteliv [Formation of a healthy lifestyle in future teachers]. Monograph. Poltava, 432 p. [in Ukrainian].

2. Bondarenko, H.L. \& Vashchenko, O.M. (2019). Analiz rezultativ doslidzhennia problemy formuvannia hotovnosti maibutnikh uchyteliv do vykorystannia zdoroviazberezhuvalnykh tekhnolohii u pochatkovii shkoli [Analysis of the results of the study of the problem of forming the readiness of future teachers to use health technologies in primary school]. International scientific journal "Education and Science". No.1 (26). pp. 83-88. [in Ukrainian]. 
3. Vashchenko, O. M. \& Svyrydenko, S. O. (2008). Ozdorovcha robota na HPD [Health work during extended day groups]. Methodical guide. Primary education. pp.311. [in Ukrainian].

4. Vashchenko, O. M. (2017). Pedahohichni umovy orhanizatsiia zdoroviazberezhuvalnoho seredovyshcha pochatkovoi shkoly [Pedagogical conditions, organization of the health-preserving environment of primary school]. Health education. Chernihiv, Vol.1. pp.119-125. [in Ukrainian].

5. Vashchenko, O. M. \& Kikosh, O. V. (2014). Pidhotovka maibutnoho vchytelia do zdoroviazberezhuvalnoi diialnosti u pochatkovii shkoli yak naukova problema [Preparing future teachers for health care activities in primary school as a scientific problem]. Pearls of scientific research: coll. Science. articles. Khmelnytskyi, book.2. pp. 18-24. [in Ukrainian].

6. Dolynskyi, B.T.(2010). Metodolohiiazdoroviazberihaiuchoi diialnosti maibutnoho vchytelia pochatkovoi shkoly [Methodology of health-preserving activity of the future primary school teacher]. Odessa, 266 p. [in Ukrainian].
7. Kondratiuk, S.M. (2003). Intehratyvnyi pidkhid do vykhovannia u molodshykh shkoliariv zdorovoho sposobu zhyttia [An integrative approach to educating younger students in a healthy lifestyle]. Extended abstract of candidate's thesis. Kyiv, $20 \mathrm{p}$. [in Ukrainian].

8. Naumenko, Yu.V. (2005). Zdoroviazberezhuvalna diialnist shkoly [School health activities]. Pedagogy. pp.3744. [in Ukrainian].

9. Natsionalna doktryna rozvytku osvity Ukrainy u XXI stolitti (2001). [National doctrine of education development of Ukraine in the XXI century]. School world.Kyiv, 24 p. [in Ukrainian].

10. Smirnov, N.K. (2002). Zdorovesberegayushchie obrazovatelnye tekhnologii v sovremennoy shkole [Healthsaving educational technologies in the modern school]. Moscov, 121p.[in Russian].

11. Cokpatova, N.V. (2005). Covpemennye tekhnologii cokhpaneniya i ukpepleniya zdopovya detey [Modern technologies of preservation and strengthening of health of children]. Study aid. Moscov, 224 p. [in Russian].

УДК 7717 [378.147:51]:[37.091.212:62]

DOI:

Альона Коломієць, кандидат педагогічних наук, доцент, доцент кафедри вищої математики Вінницького національного технічного університету

\title{
ПОБУДОВА ПЕДАГОГІЧНОЇ СИСТЕМИ ФУНДАМЕНТАЛІЗАЦІЇ МАТЕМАТИЧНОЇ ПІДГОТОВКИ МАЙБУТНІХ БАКАЛАВРІВ ТЕХНІЧНИХ СПЕЦАЛЛЬОСТЕЙ
}

У статті розглянуто основні підходи до визначення понять “фундаменталізачія”, “система”, “педагогічна система”, проведено аналіз досліджень науковців з обраної теми; проаналізовано підходи до тлумачення дефініцій “фундаменталізація”, “система”, названо основні функціональні компоненти ПС фундаменталізації математичної підготовки майбутніх бакалаврів технічних спеціальностей, наведено приклад фундаменталізації математичних понять для студентів технічних спеціальностей. Проведено опис елементів системи фундаменталізації математичної підготовки майбутніх бакалаврів технічних спеціальностей. До ї̈ складових віднесено гностичну, організаторську, конструктивну, комунікативну, проектувальний складові.

Ключові слова: майбутні бакалаври; технічні спеціальності; математична підготовка; педагогічна система; системний підхід; фундаменталізація; фундаменталізачія математичної підготовки.

Рис. 1. Табл. 2. Літ. 13.

\author{
Alona Kolomiiets, Ph.D.(Pedagogy), Associate Professor \\ Associate Professor of the Higher Mathematics Department \\ Vinnytsya National Technical University
}

\section{BUILDING A PEDAGOGICALSYSTEM FUNDAMENTALIZATION OF MATHEMATICAL PREPARATION OF FUTURE BACHELOR OF TECHNICAL SPECIALTIES}

The main approaches to the definition of the concepts of fundamentalization system, pedagogical system are considered in the work, the analysis of researches of scientists on the chosen theme is carried out. The precondition for the problem of fundamentalization of mathematical training of students of technical specialties was the rapid growth of mathematical knowledge and the impossibility of their reflection in the structure of the educational process of students of technical specialties. The search for ways to solve this problem led to the idea of fundamentalization, which involves the selection and study of fundamental sections, topics, concepts of the discipline in accordance with the technical specialty in which students study.

One of the preconditions that led to the emergence of a systematic approach was the attempt of scientists to 